\title{
Prevalence of Oral Mucosal Lesions in Children
}

\author{
Prevalencia de Lesiones de la Mucosa Oral en Niños
}

Yáñez M. ; Escobar E."; Oviedo C."; Stillfried A." \& Pennacchiotti G."

YÁÑEZ, M.; ESCOBAR, E.; OVIEDO, C.; STILLFRIED, A.; PENNACCHIOTTI, G. Prevalence of oral mucosal lesions in children. Int. J. Odontostomat., 10(3):463-468, 2016.

ABSTRACT: Lesions of the oral mucosa are a broad range of different alterations located in the soft tissue of the oral cavity. The studies that describe the prevalence of oral mucosal lesions have been carried out mainly in an adult population. Therefore, in the literature available both in Chile and abroad, there are few reports about pathological lesions and alterations of the normality of the oral mucosa in pediatric population. A descriptive observational cross-sectional study was conducted, with non-probability sampling for convenience, with a sample of 219 patients and a level of confidence of $95 \%$. We estimated $30 \%$ of children with oral mucosal lesions. Patient history and the presence of oral mucosal lesions were registered in the clinical records specific to this study. In 101 patients a prevalence of $37.62 \%$ of oral mucosal lesions was observed. The most frequent lesion was the minor aphthous ulcer $(6.9 \%)$, followed by irritation fibroma (5\%), traumatic ulcer (5\%), traumatic erosion (4\%), impetigo (4\%), pigmented lesion (3\%), and others, at lower rates. The most prevalent location was the lips with a $38.5 \%$.

KEY WORDS: oral mucosal lesions, pediatric population, traumatic ulcers, aphthous stomatitis.

\section{INTRODUCTION}

Oral mucosal lesions are a broad group of alterations located in the soft tissues of the oral cavity, recognizable by their etiology, clinical characteristics, prognosis, and dissimilar treatments.

The clinical exam to obtain a diagnosis of oral conditions and lesions is fundamental, which is why, it must be correct, thorough, and systematic. The exam of soft tissues in pediatric patients involves knowledge of normal size, shape, color, and texture of the structures that comprise it. The correct exploration of the oral mucosa can provide important tools in diagnosing developmental, neoplastic, infectious, or inflammatory alterations (Espinoza et al., 2003).

The lesions in oral mucosa in children can present as vesicles, ulcers, macules, changes in color, size alterations, and configuration of the oral anatomy (Donoso et al., 2013).

In Chile, there are few studies about oral mucosal lesions, neither in adult or pediatric populations (Kramer et al., 1980; Cueto et al., 2013; Pinto et al., 2014). On the other hand, it is important to organize and standardize the criteria of examination for the various medical procedures in oral mucosa.

Several studies in different geographic locations have reported frequency in oral mucosal lesions. In a study conducted in Argentina by Muniz et al., in 1981, for a total sample of 75 healthy pediatric male patients, ages 6 to 13, 46 patients presented oral mucosal lesions, with a prevalence of $61.3 \%$. The most common lesions were angular cheilitis (14.7\%), followed by herpes labialis $(10.7 \%)$, impetigo $(9.3 \%)$, geographic tongue, recurrent aphthous ulcer, and verruca vulgaris (2.7 \%) (Muñiz et al., 1981).

In a study carried out in South Africa by Arendorf et al. (1996), with a sample of 1051 patients, a 32.90 $\%$ prevalence of oral mucosal lesions was observed. The most prevalent was the recurrent aphthous ulcer (10.87\%), followed by herpes labialis (5.2\%), angular cheilitis (3.54\%), geographic tongue $(2.95 \%)$,

\footnotetext{
* DS. Universidad del Desarrollo, Chile.

${ }^{*}$ MSc Oral Pathology and Medicine. Universidad de Chile.
} 
depapillated tongue $(2.6 \%)$, ankyloglossia, traumatic ulcer $(1.41 \%)$, mucocele (1.18\%) and impetigo (0.94 \%) (Arendorf et al.).

In Mexico, Espinoza-Zapata (2006) conducted a study with a sample of 1165 patients between 1 and 16 years old. The prevalence of oral mucosal lesions was $7.4 \%$. The most frequent lesions were: fibrous hyperplasia (3.18\%), oral candidiasis (1.89\%), and ulcerative lesions (1.2\%) (Espinoza-Zapata et al.).

\section{MATERIAL AND METHOD}

An observational, descriptive study was conducted. Non-probability sampling was used for convenience depending on scheduling and availability of the patients from the Pediatric Dentistry Clinic of the Universidad del Desarrollo. A sample of 219 patients from a population of 680 patients treated at that clinic in the year 2014, with a $95 \%$ level of confidence, $5 \%$ margin of error, and an estimated of $30 \%$ of the pediatric patients with oral mucosal lesions. The sample was distributed into two groups: healthy patients and patients with systemic diseases.

The inclusion criteria were patients from 3 years old to 13 years old, both genders.

The sample was examined between July and September in 2015. This study was approved by the undergraduate research Ethics Committee of the Faculty of Medicine - Clínica Alemana of Universidad del Desarrollo, and before carrying out the clinical trial; the patients and their proxies signed an informed consent and assent.

In this study, the instrument used for measuring was the clinical record, based on the clinical exam of the oral mucosa applied by the World Health Organization described in the study "Guide to epidemiology and diagnosis of oral mucosal diseases and conditions" (Espinoza et al.) and in "Pediatric Oral Medicine" a guide of pediatric oral medicine (Witman et al., 2003), where the general data about children was registered by illnesses, type, and location of the lesion. This was carried out through direct observation without using complementary exams, which is why the diagnosis was based on the clinical exam. In case of finding any oral mucosal lesion, a photographic register of the lesion was taken.

The results obtained in the clinical records were processed using Microsoft Office Excel 2011® worksheet, where a descriptive statistic was made, doing statistical process of data.

\section{RESULTS}

One hundred one pediatric patients were examined in the pediatric dentistry clinic in the UDD clinic from July to September 2015, where all of the patients studied fitted the inclusion criteria.

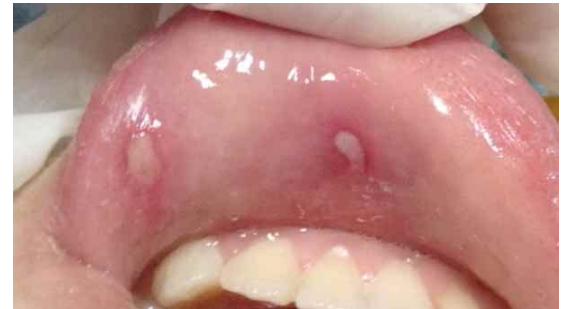

Fig. 1. Minor aphthous ulcer on labial mucosa.

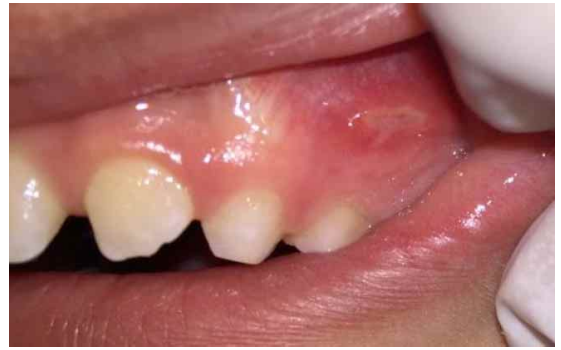

Fig. 2. Traumatic ulcer on the oral groove.

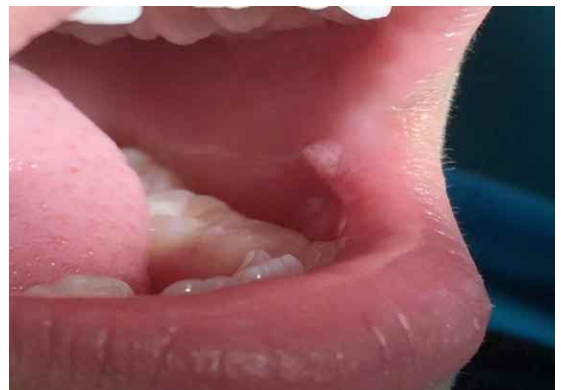

Fig. 3. Irritated Fibroid on oral mucosa.

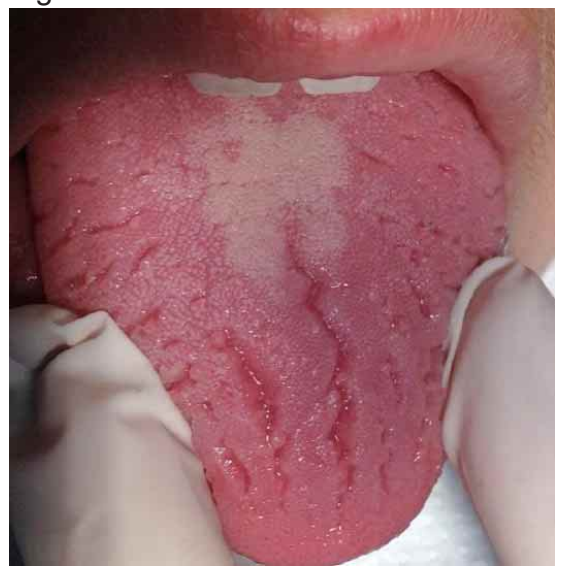

Fig. 4. Fissured tongue on dorsum of the tongue.

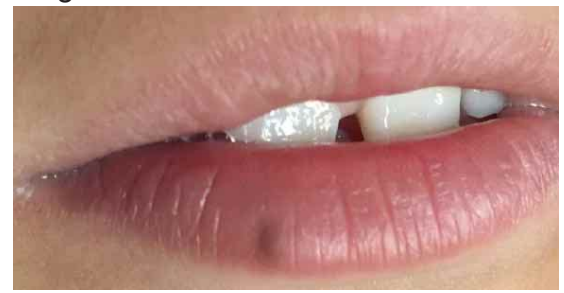

Fig. 5. Pigmented lesion on vermilion margin. 
In this group of 101 patients, 47 (46.5\%) were men and $54(53.5 \%)$ were female. The age group of the patients was from 4 to 13 years of age, with a median of 8 , and a mean of 8.7 years old.

Of the entirety of the sample, 38 patients $(37.6$ $\%)$ were diagnosed with at least one oral mucosal lesion during the exam. The frequency percentages of oral mucosal lesion in men and female were $36.2 \%$ in the former and $38.9 \%$ in the latter. Of these, only one patient had two lesions simultaneously $(2.6 \%)$.

In Table I, the diagnosis of the 39 oral mucosal lesions in 38 patients can be appreciated. The more

Table I. Oral mucosal lesions presented in 38 patients. (1 patient presented 2 simultaneous diagnosis).

\begin{tabular}{lc}
\hline \multicolumn{1}{c}{ Type of lesion } & Number of lesions found \\
\hline Minor aphth ous ulcers & 7 \\
Irritation fibroma & 5 \\
Traumatic ulcer & 5 \\
Traumatic erosion & 4 \\
Impetigo & 4 \\
Pigmented lesions & 3 \\
Recurrent herpes labialis & 2 \\
Recurrent intraoral herpes & 1 \\
Mucocele & 1 \\
Ranula & 1 \\
Telangiectatic granuloma & 1 \\
Fisured tongue & 1 \\
Geographic tongue & 1 \\
Submucous abscess & 1 \\
Morsicatio buccarum & 1 \\
Gingivitis caused by friction & 1 \\
\hline
\end{tabular}

Table II. Frequency of oral mucosal lesions distributed by anatomical location.

\begin{tabular}{lcc}
\hline Anatomical location & $\begin{array}{c}\text { Frequency } \\
\text { of lesions }\end{array}$ & $\begin{array}{l}\text { Prevalence } \\
\text { of lesions }\end{array}$ \\
\hline Labial mucosa & 9 & $23.08 \%$ \\
Vermilion margin & 6 & $15.38 \%$ \\
Oral mucosa & 5 & $12.79 \%$ \\
Labial commissures & 3 & $7.69 \%$ \\
Oral groove & 3 & $7.69 \%$ \\
Gingiva & 3 & $7.69 \%$ \\
Floor of the oral cavity & 3 & $7.69 \%$ \\
Dorsum of tongue & 2 & $5.09 \%$ \\
Apex of tongue & 2 & $5.09 \%$ \\
Attached mucosa & 1 & $2.60 \%$ \\
Hard palate & 1 & $2.60 \%$ \\
Tonsil lar pillars & 1 & $2.60 \%$
\end{tabular}

prevalent lesions were minor aphthous ulcers (6.9\%), irritation fibroma (5\%), traumatic ulcer (5\%), traumatic erosion (4\%), impetigo (4\%), pigmented lesions (3 $\%)$, and recurrent herpes labialis (2\%).

Respecting the anatomical location of the oral mucosal lesions, 9 were located on labial mucosa, 6 on the vermillion border, 5 on buccal mucosa, 3 on labial commissures, 3 on gingiva, 3 on the floor of the mouth, 3 on the buccal groove, 2 on dorsum of the tongue, 2 on apex of the tongue, 1 attached mucosa, 1 on the hard palate, and 1 on the tonsillar pilar (Table II).

\section{DISCUSSION}

The prevalence of oral mucosal lesions in this study was of $37.6 \%$ of the studied pediatric population. In the revised studies, this percentage varies from a $4.1 \%$ (Arendorf et al.) to a $78.4 \%$ (Espinoza-Zapata et al.). Even though the demographic characteristics of the studied population are different, the percentage of the lesions found in this study is very similar to the prevalence found in Argentina by Crivelli et al. (1988) being this one a $39.04 \%$; and also very similar to the one in Spain by García-Pola et al. (2002) which was $38.94 \%$.

The most prevalent pathologies were minor aphthous ulcer $(6.9 \%)$, irritation fibroma (5\%), traumatic ulcer (5\%), traumatic erosion (4\%), impetigo $(4 \%)$, pigmented lesions (3\%), herpes labialis $(2 \%)$, intraoral herpes $(1 \%)$, mucocele $(1 \%)$, ranula $(1 \%)$, telangiectasic granuloma ( $1 \%)$, fissured tongue $(1 \%)$, geographic tongue $(1 \%)$, submucous abscess $(1 \%)$, morsicatio buccarum (1\%), and gingivitis caused by friction (1\%).

The most frequent location observed in oral mucosal lesions, was labial mucosa $(23.1 \%)$, followed by vermilion border (15.4\%), buccal mucosa $(12.8 \%)$, labial commissures $(7.7 \%)$, buccal groove $(7.7 \%)$, gingiva $(7.7 \%)$, floor of the mouth $(7.7 \%)$, apex of the tongue $(5.1 \%)$ dorsum of the tongue $(5.1 \%)$, attached mucosa $(2.6 \%)$, tonsillar pillars $(2.6 \%)$, hard palate $(2.6 \%)$. The anatomical location is similar to the one observed by Shulman (2005) with $30.7 \%$ on lips, and the one by Hussein \& Noori (2014) with a $37.4 \%$ on lips.

This study shows a tendency of frequent diagnoses of oral mucosal lesions that could be found 


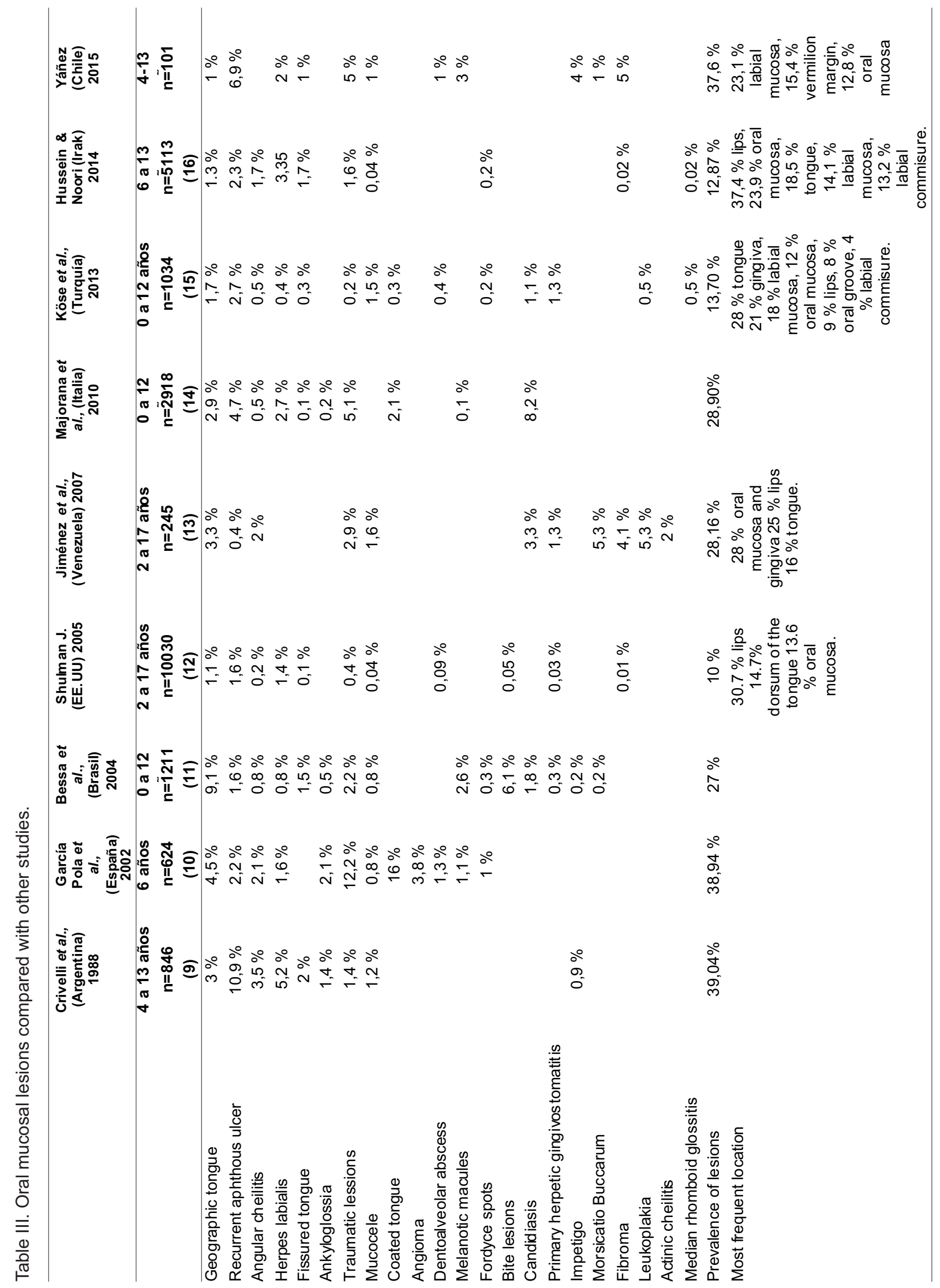


in the Chilean population. The diagnosis of these oral mucosal lesions is a challenge for the dentist because of its varied clinical expression, which is why, early and adequate diagnosis, allows the application of accurate therapeutic proposals. It is important to continue this line of investigation in other pediatric populations in Chile and extending the sample size.

\section{CONCLUSIONS}

This study describes the frequency of oral mucosal lesions found in 38 patients out of 101 examined in the Pediatric Dentistry Clinic of Universidad del Desarrollo in 2015 from July to September.

The prevalence of oral mucosal lesions was 37.6 $\%$, similar to other epidemiological studies (Crivelli et al.; García-Pola et al.). In the group of healthy patients prevalence was $35.3 \%$, and in the group of patients with systemic diseases it was $50 \%$.

The minor aphthous ulcer was the most prevalent oral mucosal lesion, followed by irritation fibroma, and traumatic ulcers. The most frequent anatomical location was labial mucosa $(23.08 \%)$. The most frequent age range was from 9 to 13 years old with $19.8 \%$ of prevalence in oral mucosal lesions.

Even though most of the oral mucosal lesions evaluated in this study can be diagnosed in a purely clinical way; there are some oral mucosal lesions that need confirmation through an anatomopathological study. The time for data collection and the fact that there was only one examiner limited the ability to reach the sample size proposed at the beginning.

YÁÑEZ, M.; ESCOBAR, E.; OVIEDO, C.; STILLFRIED, A. \& PENNACCHIOTTI, G. Prevalencia de lesiones de la mucosa oral en niños. Int. J. Odontostomat., 10(3):463-468, 2016.

RESUMEN: Las lesiones de la mucosa oral comprenden un amplio conjunto de alteraciones que se localizan en los tejidos blandos de la cavidad oral. Los estudios que describen la prevalencia de lesiones de mucosa oral, se han realizado principalmente en población adulta, por lo tanto en la literatura internacional y en Chile, existen escasos reportes acerca de lesiones patológicas y alteraciones de la normalidad de mucosa oral en población pediátrica. Se realizó un estudio observacional, descriptivo y transversal, de tipo no probabilístico por conveniencia, donde se calculó una muestra de 219 pacientes con un nivel de confianza de $95 \%$. Se estimó un porcentaje de $30 \%$ de niños con lesiones de mucosa oral. Se registró la anamnesis del paciente y presencia de lesiones de mucosa oral en la ficha clínica específica para el estudio. Se observó en 101 pacientes una prevalencia de 37,62 \% de lesiones de mucosa oral. La lesión más frecuente fue el afta menor, seguido de fibroma irritativo, úlcera traumática, erosión traumáticas, impétigo, lesiones pigmentadas y entre otras con menor frecuencia. La localización más prevalente fue los labios con $38,5 \%$.

PALABRAS CLAVE: lesiones de mucosa oral, población pediátrica, úlceras traumáticas, estomatitis aftosa.

\section{REFERENCES}

Arendorf, T. M. \& van der Ross, R. Oral soft tissue lesions in a black pre-school South African population. Community Dent. Oral Epidemiol., 24(4):296-7, 1996.

Bessa, C. F.; Santos, P. J.; Aguiar, M. C. \& do Carmo, M. A. Prevalence of oral mucosal alterations in children from 0 to 12 years old. J. Oral Pathol. Med., 33(1):17-22, 2004.

Crivelli, M. R.; Aguas, S.; Adler, I.; Quarracino, C. \& Bazerque, $P$. Influence of socioeconomic status on oral mucosa lesion prevalence in schoolchildren. Community Dent. Oral Epidemiol., 16(1):58-60, 1988.
Cueto, A.; Martínez, R.; Niklander, S.; Deichler, J.; Barraza, A. \& Esguep, A. Prevalence of oral mucosal lesions in an elderly population in the city of Valparaiso, Chile. Gerodontology, 30(3):201-6, 2013.

Espinoza, I.; Rojas, R.; Aranda, W. \& Gamonal, J. Prevalence of oral mucosal lesions in elderly people in Santiago, Chile. J. Oral Pathol. Med., 32(10):571-5, 2003.

Espinosa-Zapata, M.; Loza-Hernández, G. \& Mondragón-Ballesteros, R. Prevalencia de lesiones de la mucosa bucal en pacientes pediátricos. Informe preliminar. Cir. Cir., 74(3):153-7, 2006. 
García-Pola, M. J.; García-Martin, J. M. \& Gonzalez-Garcia, M. Prevalence of oral lesions in the 6-year-old pediatric population of Oviedo (Spain). Med. Oral, 7(3):184-91, 2002.

Hussein, S. A. \& Noori, A. J. Prevalence of oral mucosal changes among 6-13-year old children in Sulaimani city, Iraq. Sulaimani Dent. J., 1:5-9, 2014.

Jiménez-Palacios, C.; Ramírez, R.; Ortiz, V.; Virgüez, V. \& Benítez, A. Identificación de lesiones en los tejidos blandos de la cavidad bucal en adolescentes con privación de libertad en el odontopediátrico de carapa. Septiembre 2005- abril 2006 Venezuela. Acta Odontol. Venez., 47(2):327-33, 2009.

Jiménez-Palacios, C.; Kkilikan, R.; Ramírez, R.; Ortiz, V.; Virgüez, Y. \& Benítez, A. Levantamiento epidemiológico de lesiones patológicas en tejidos blandos de la cavidad bucal de los niños y adolescentes del centro odontopediátrico de Carapa, Parroquia Antímano, Caracas, Distrito Capital, Venezuela. Período Mayo-Noviembre 2005. Acta Odontol. Venez., 45(4):540-5, 2007.

Kramer, I. R.; Pindborg, J. J.; Bezroukov, V. \& Infirri, J. S. Guide to epidemiology and diagnosis of oral mucosal diseases and conditions. World Health Organization. Community Dent. Oral Epidemiol., 8(1):1-26, 1980.

Köse, O.; Güven, G.; Özmen, I.; Akgün, Ö. M. \& Altun, C. The oral mucosal lesions in pre-school and school age Turkish children. J. Eur. Acad. Dermatol. Venereol., 27(1):e136-7, 2013.

Majorana, A.; Bardellini, E.; Flocchini, P.; Amadori, F.; Conti, G. \& Campus, G. Oral mucosal lesions in children from 0 to 12 years old: ten years' experience. Oral Surg. Oral Med. Oral Pathol. Oral Radiol. Endod., 110(1):e13-8, 2010.

Muñiz, B.; Crivelli, M. \& Paroni, H. Clinical study of oral soft tissue lesions in boys in a children's home. Rev. Asoc. Odontol. Argent., 69(7):405-8, 1981.

Pinto, A.; Haberland, C. M. \& Baker, S. Pediatric soft tissue oral lesions. Dent. Clin. North Am., 58(2):437-53, 2014.

Shulman, J. D. Prevalence of oral mucosal lesions in children and youths in the USA. Int. J. Paediatr. Dent., 15(2):8997, 2005.

Witman, P. M. \& Rogers III, R. S. Pediatric oral medicine. Dermatol. Clin., 21(1):157-70, 2003.
Correspondience to:

Ma. Soledad Yáñez

Universidad del Desarrollo

CHILE

Email: mayanezc@gmail.com

Received: 08-09-2016

Accepted: 14-11-2016 